\title{
The Mycorrhizal Population Dynamics and Wilt Intensity in Chilli Growing Areas of Haryana
}

\author{
Sarita and Rakesh Kumar Chugh* \\ Department of Plant pathology, CCS Haryana Agricultural University Hisar, India \\ *Corresponding author
}

\section{A B S T R A C T}

Keywords

Fusarium

oxysporum,

Mycorrhizal

population,

Sporocarp,

Mycorrhizal

colonization and

survey

Article Info

Accepted:

26 April 2020

Available Online:

10 May 2020
The major diseases affecting chilli productions are Anthracnose, Phytopthora, Leaf blight, Fusarium wilt, bacterial wilt, damping-off and root rot etc. Among these, Fusarium wilt caused by the Fusarium oxysporum has emerged as a serious problem in recent year. In this investigation, to study the mycorrhizal population dynamics and wilt intensity in chilli growing areas of state, the survey was undertaken during crop season 2017-18 in Hisar, Fatehabad and Mohindergarh districts. Two to three field from each village and total ten fields were observed from each district. The mycorrhizal per cent colonization in roots and number of sporocarp in soil was maximum in Mahendragarh (13.4 per cent mycorrhizal colonization and 83 sporocarps/ 100g soil) followed by Fatehabad district (7.5 per cent mycorrhizal colonization and 63.3 sporocarps/ 100g soil) and minimum in Hisar district (4.7 per cent mycorrhizal colonization and 39.4 sporocarps/ 100g soil). The maximum wilt intensity was recorded from the Fatehabad district (7.9 per cent), followed by Mahendragarh (7.3 per cent) and minimum from Hisar (5.2 per cent). Glomus spp. was prevalent in all the districts surveyed.

\section{Introduction}

In India chilli (Capsicum annuum L.) is one of the most important commercial spice crops. It is preferred for its pungency, spicy taste and color which give nice flavor to the food. The major diseases affecting chilli productions are Anthracnose, Phytopthora, Leaf blight, Fusarium wilt, bacterial wilt, damping-off and root rot etc. Among these, Fusarium wilt caused by the Fusarium oxysporum has emerged as a serious problem in recent year.
Chilli is attacked by a large number of pathogens, out of them Fusarium oxysporum causing vascular wilt is the most predominant and causes 10-50 per cent crop losses around the world and 10-80 per cent in India (Bai et $a l, 2018)$. Major chilli producing states in India are Karnataka, Madhya Pradesh, Andhra Pradesh, Bihar and Maharashtra (Anonymous, 2017). In India Chilli occupies an area of 399 thousand hectares with an annual production of 3737 M. tonnes (Anonymous, 2019). In Haryana chilli occupies an area of 18.65 
thousand hectares with production of 130.96 M. tonnes (Anonymous, 2017). Wilt is highly damaging disease of chilli crop causing significant reduction in yield because it blocks the xylem vessel and there is no uptake of nutrient and minerals by plant, which result in death of plant. Mycorrhiza is a symbiotic association between a fungus and the root system of vascular plants. Mycorrhizal associations help the host plants to thrive in adverse soil conditions and drought situations by increasing the root surface area and mineral uptake efficiency. AM fungi are obligate biotrophs, solely dependent on the host plants for their survival. Some bioactive molecules like strigolactones secreted by the roots help fungi to identify their host plants. Strigolactones also stimulate AM fungal growth and its branching. Arbuscular Mycorrhiza (AM) is well known for their plant growth promoting efficiency and providing bio protection against soil borne pathogens (bacteria, fungal and parasitic nematode). Soil borne plant pathogens are difficult to be controlled by conventional fungicidal methods.

\section{Materials and Methods}

\section{Study area}

To study the mycorrhizal population dynamics and wilt intensity in chilli growing areas of state, observations were documented in field and laboratory conditions. Two to three field from each village and total ten fields were observed from each district (Fatehabad, Hisar and Mahindergarh). Plant Pathology Laboratory, CCS HAU, Hisar was use for the laboratory work. The survey was undertaken during crop season 2017-18.

\section{Survey}

Ten fields were visited in each district (Hisar, Fatehabad and Mahendragarh). At each site, ten plants were uprooted and their roots were examined and wilt intensity was calculated by the scale (Saha et al., 2007). Root samples were collected from each site in polythene bag for calculating mycorrhizal colonization in roots. About $250 \mathrm{~g}$ soil was collected for the estimation of sporocarp number in soil.

\section{Mycorrhizal colonization}

Mycorrhizal colonization was calculated by Staining of roots by following procedure given by Phillips and Hayman (1970).

\section{Staining of root}

Roots were cut into $1 \mathrm{~cm}$ segments, heat the roots in 10 per cent $\mathrm{KOH}$ at $90^{\circ} \mathrm{C}$ for one hour, washed these roots with fresh (10 per cent) $\mathrm{KOH}$ solution, immersed roots in alkaline hydrogen peroxide $\left(\mathrm{H}_{2} \mathrm{O}_{2}\right)$ for 30 minutes. Then rinsed with distilled water to remove the excess of $\mathrm{H}_{2} \mathrm{O}_{2}$ and acidified with $5 \mathrm{~N}$ HCL for 30 minutes. Roots were simmering in trypane blue in lactophenol $(0.05 \%)$ for $5 \mathrm{~min}$. Finally, roots were put in lactophenol to remove the extra dye and examine the roots under microscope.

\section{Mycorrhizal colonization (\%) in roots}

$$
=\frac{\text { Sum of all numerical ratings } \times 100}{\text { Total number of sample assessed } \times \text { Maximum scale }}
$$

\section{Estimation of sporocarp in soil}

About $250 \mathrm{~g}$ soil was collected for the estimation of sporocarp number in soil by Gerdemann and Nicolson (1963).Estimation of sporocarp in soil was done by Wet Sieving and Decantation Technique given by Gerdemann and Nicolson (1963).

Firstly, the soil sample was mixed well and then $100 \mathrm{~g}$ soil was suspended in a pan A add one liter of water and mix it well. Wait for 30 seconds. Suspension was passed through 20 mesh sieve and filtrate was collected into a pan B. Material of pan A was discard. 
Suspension of B pan was stirred with hand and allows it for few second to settled down then passed through 60 mesh sieve. Filtrate was collected in pan C. Suspension of pan C was passed through the 100 mesh sieve. Maximum mature sporocarps were collected on 100 mesh sieve. One hundred mesh sieve residue was collected into a beaker after washing in order to remove the excess soil and other particles. $1 \mathrm{ml}$ of this solution was taken in counting dish and examined under stereomicroscope microscope and count the sporocarp population in soil.

\section{Wilt intensity}

Disease intensity

$=\frac{\text { Sum of all numerical ratings } \times 100}{\text { Total number of plant assessed } \times \text { Maximum scale }}$

Fusarium wilt disease rating scale was given by Saha et al., (2007).

\section{0-3 disease rating scale}

$0=$ No infection/healthy - Resistant $(\mathrm{R})$

1 = Leaf yellowing - Moderately resistant (MR)

$2=$ Leaf yellowing + plant wilting Moderately susceptible (MS)

3 = Leaf yellowing + plant wilting + plant death - Susceptible (S)

\section{Results and Discussion}

\section{Mycorrhizal population dynamics}

The study indicates that, the mycorrhizal colonization was ranged 1 to 17.3 per cent and sporocarp number in soil was ranged 9 to130. Wilt intensity was ranged 0.5 to 7.9 . The mycorrhizal per cent colonization and number of sporocarp in soil was maximum in Mahendragarh (13.4 per cent mycorrhizal colonization and 83 sporocarps/ 100g soil) followed by Fatehabad district (7.5 per cent mycorrhizal colonization and 63.3 sporocarps/ $100 \mathrm{~g}$ soil) and minimum in Hisar district (4.7 per cent mycorrhizal colonization and 39.4 sporocarps/ 100g soil).

In Hisar district the mycorrhizal colonization and number of sporocarp in soil was low in sample collected from Hansi (1 per cent mycorrhizal colonization and 9 sporocarps/ $100 \mathrm{~g}$ soil), whereas in village Kharar- Alipur (11.5 per cent mycorrhizal colonization and 69 sporocarps/ 100g soil) highest mycorrhizal per cent colonization and number of sporocarp in soil were reported. Village Dhani Bikaneri of Fatehabad district had lowest (1.5 per cent mycorrhizal colonization and 10 sporocarps/ 100g soil) and Dani BinjaLamba (13.1 per cent mycorrhizal colonization and 91 sporocarps/ 100g soil) had highest mycorrhizal colonization and number of sporocarp in soil. Similarly, in Mahendragarh district village Dongra Ahir had lowest (7.4 per cent mycorrhizal colonization and 29 sporocarps/ 100g soil) and Ateli (17.3 per cent mycorrhizal colonization and 130 sporocarps/ 100g soil) had highest mycorrhizal colonization and number of sporocarp in soil respectively.

In Hisar district Glomus spp. was prevalent in 70 per cent of the field surveyed the other were Aculospora spp. and Gigaspora spp. In Fatehabad district 40 percent Glomus spp. and 40 per cent Gigaspora spp. rest 20 per cent Aculospora spp. were present. Further, in the third district i.e. Mohindergarh 70 per cent and others were Gigaspora spp. and Aculospora spp. (Table 1)

\section{Wilt intensity}

During survey in Haryana the maximum wilt intensity was recorded from the Fatehabad district (7.9 per cent), followed by Mahendragarh (7.3 per cent) and minimum from Hisar (5.2 per cent) during the cropping session 2017-18 (Table 2). 
Table.1 Survey for Mycorrhizal population dynamics in the chilli fields in different district of Haryana

\begin{tabular}{|c|c|c|c|c|c|c|}
\hline $\begin{array}{c}\text { Sr. no. } \\
\text { of } \\
\text { Field }\end{array}$ & State & District & Locality & $\begin{array}{c}\text { Mycorrhyzal } \\
\text { colonization } \\
(\%)\end{array}$ & $\begin{array}{c}\text { Sporocarp } \\
\text { number/ } \\
100 \mathrm{~g} \text { soil }\end{array}$ & $\begin{array}{l}\text { Myocrrhizal } \\
\text { Species }\end{array}$ \\
\hline 1 & \multirow[t]{30}{*}{ Haryana } & \multirow[t]{10}{*}{ Hisar } & Hisar & 5.3 & 50 & Glomus sp. \\
\hline 2 & & & Hisar & 4.0 & 41 & -do- \\
\hline 3 & & & Hisar & 2.0 & 28 & -do- \\
\hline 4 & & & Hansi & 1.0 & 9 & Gigaspora sp \\
\hline 5 & & & Hansi & 3.0 & 24 & Aculospora sp \\
\hline 6 & & & Balsamad & 5.0 & 30 & Glomus sp. \\
\hline 7 & & & Balsamad & 3.0 & 42 & -do- \\
\hline 8 & & & Kharar-Alipur & 10.0 & 52 & Aculospora sp \\
\hline 9 & & & Kharar-Alipur & 11.5 & 69 & Glomus sp. \\
\hline 10 & & & Kharar-Alipur & 10.9 & 49 & Glomus sp. \\
\hline 1 & & \multirow[t]{10}{*}{ Fatehabad } & $\begin{array}{l}\text { Dani Binja } \\
\text { Lamba }\end{array}$ & 12.2 & 51 & Gigaspora sp. \\
\hline 2 & & & $\begin{array}{l}\text { Dani } \\
\text { BinjaLamba }\end{array}$ & 13.1 & 91 & -do- \\
\hline 3 & & & Bhuna & 5.2 & 65 & Glomus sp. \\
\hline 4 & & & Bhuna & 4.3 & 42 & -do- \\
\hline 5 & & & Saniana & 10.1 & 70 & Gigaspora sp. \\
\hline 6 & & & Saniana & 11.2 & 85 & -do- \\
\hline 7 & & & Dani Bikaneri & 1.5 & 10 & Aculospora sp \\
\hline 8 & & & Kharakheri & 5.0 & 53 & -do- \\
\hline 9 & & & Kharakheri & 11.3 & 90 & Glomus sp. \\
\hline 10 & & & Diwana & 9.0 & 76 & -do- \\
\hline 1 & & \multirow[t]{10}{*}{ Mahendragarh } & Dongra jat & 11.5 & 46 & Glomus sp. \\
\hline 2 & & & Dongra jat & 12.3 & 43 & Gigaspora sp. \\
\hline 3 & & & Dongra jat & 10.9 & 30 & -do- \\
\hline 4 & & & Ateli & 17.3 & 130 & Glomus sp. \\
\hline 5 & & & Ateli & 16.5 & 122 & - do- \\
\hline 6 & & & Dongra Ahir & 7.6 & 91 & -do- \\
\hline 7 & & & Dongra Ahir & 7.4 & 29 & -do- \\
\hline 8 & & & Narnaul & 15.2 & 96 & -do- \\
\hline 9 & & & Silarpur & 15.6 & 102 & Aculospora sp \\
\hline 10 & & & Silarpur & 16.1 & 128 & Glomus sp. \\
\hline
\end{tabular}


Table.2 Survey in different district of Haryana for wilt intensity in the chilli fields

\begin{tabular}{|c|c|c|c|c|c|}
\hline $\begin{array}{l}\text { Sr. no. } \\
\text { of Field }\end{array}$ & State & District & Village & Soil type & $\begin{array}{c}\text { Disease } \\
\text { intensity }(\%)\end{array}$ \\
\hline 1 & \multirow[t]{30}{*}{ Haryana } & \multirow[t]{10}{*}{ Hisar } & Hiasr & Loamy sand & 2.5 \\
\hline 2 & & & Hisar & Loamy sand & 2.0 \\
\hline 3 & & & Hansi & Loamy sand & 1.8 \\
\hline 4 & & & Hansi & Loamy sand & 5.2 \\
\hline 5 & & & Hansi & Loamy sand & 4.6 \\
\hline 6 & & & Balsamad & -do- & 5.1 \\
\hline 7 & & & Balsamad & - do- & 1.6 \\
\hline 8 & & & Kharar-Alipur & Loamy sand & 0.5 \\
\hline 9 & & & Kharar-Alipur & Loamy sand & 4.8 \\
\hline 10 & & & Kharar-Alipur & Loamy sand & 3.2 \\
\hline 1 & & \multirow[t]{10}{*}{ Fatehabad } & Dani BinjaLamba & Sandy loam & 6.1 \\
\hline 2 & & & Dani BinjaLamba & Sandy loam & 2.8 \\
\hline 3 & & & Bhuna & -do- & 7.4 \\
\hline 4 & & & Bhuna & -do- & 7.9 \\
\hline 5 & & & Dani Bikaneri & Sandy loam & 4.1 \\
\hline 6 & & & Saniana & Sandy loam & 6.8 \\
\hline 7 & & & Saniana & Sandy loam & 1.5 \\
\hline 8 & & & Kharakheri & -do- & 3.2 \\
\hline 9 & & & Kharakheri & -do- & 5.4 \\
\hline 10 & & & Diwana & -do- & 1.0 \\
\hline 1 & & \multirow[t]{10}{*}{ Mahendragarh } & Dongra jat & Sandy loam & 1.7 \\
\hline 2 & & & Dongra jat & Sandy loam & 4.3 \\
\hline 3 & & & Dongra jat & Sandy loam & 2.9 \\
\hline 4 & & & Ateli & Loamy sand & 0.8 \\
\hline 5 & & & Ateli & Loamy sand & 2.1 \\
\hline 6 & & & Dongra Ahir & Sandy loam & 4.9 \\
\hline 7 & & & Dongra Ahir & Sandy loam & 4.6 \\
\hline 8 & & & Narnaul & Sandy loam & 5.3 \\
\hline 9 & & & Silarpur & Loamy sand & 6.5 \\
\hline 10 & & & Silarpur & Loamy sand & 7.3 \\
\hline
\end{tabular}


Plate.1Survey of different district of Haryana for mycorrhizal population, sporocarp number and chilli wilt intensity
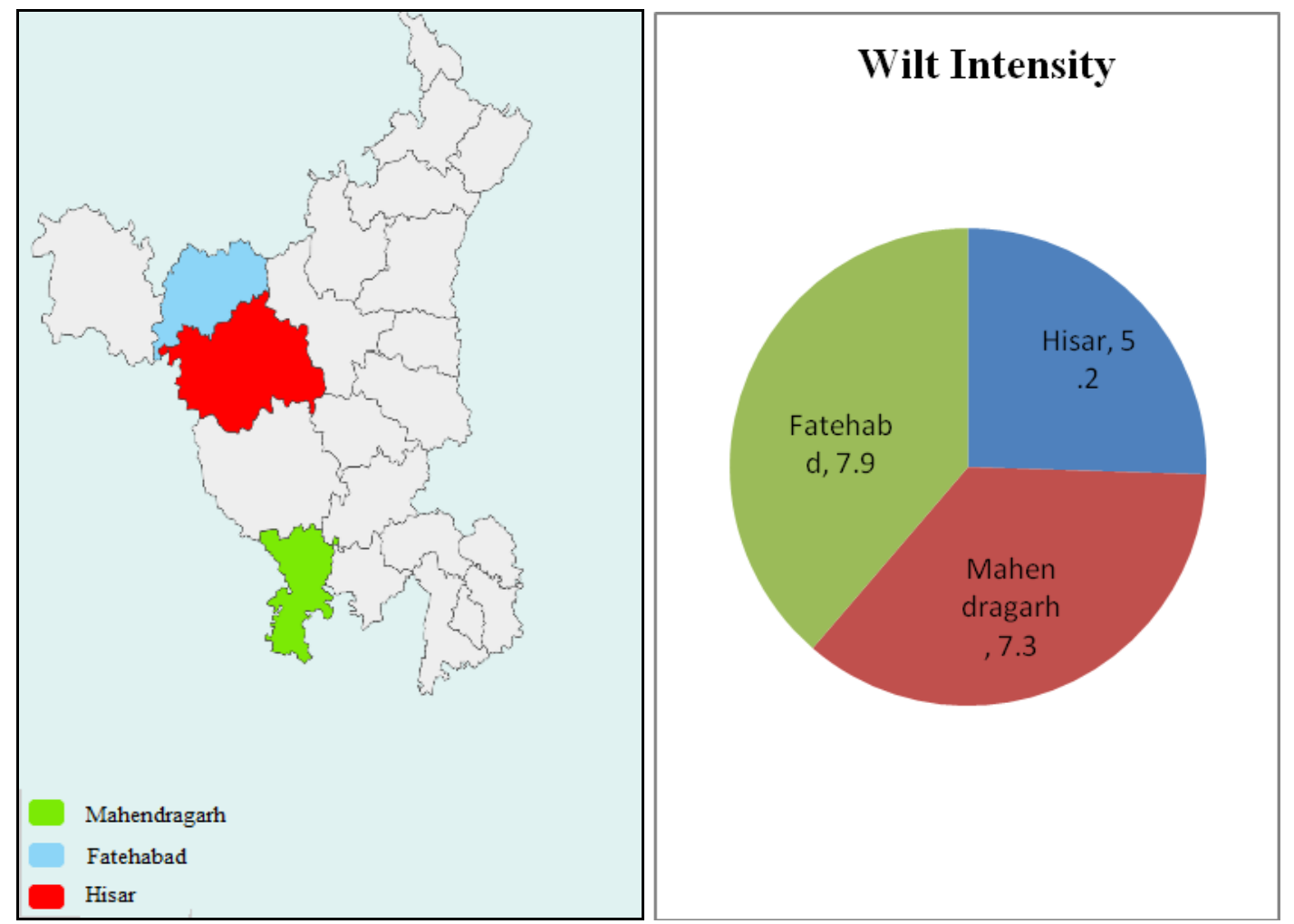

Plate.2 A general view of chilli field during survey

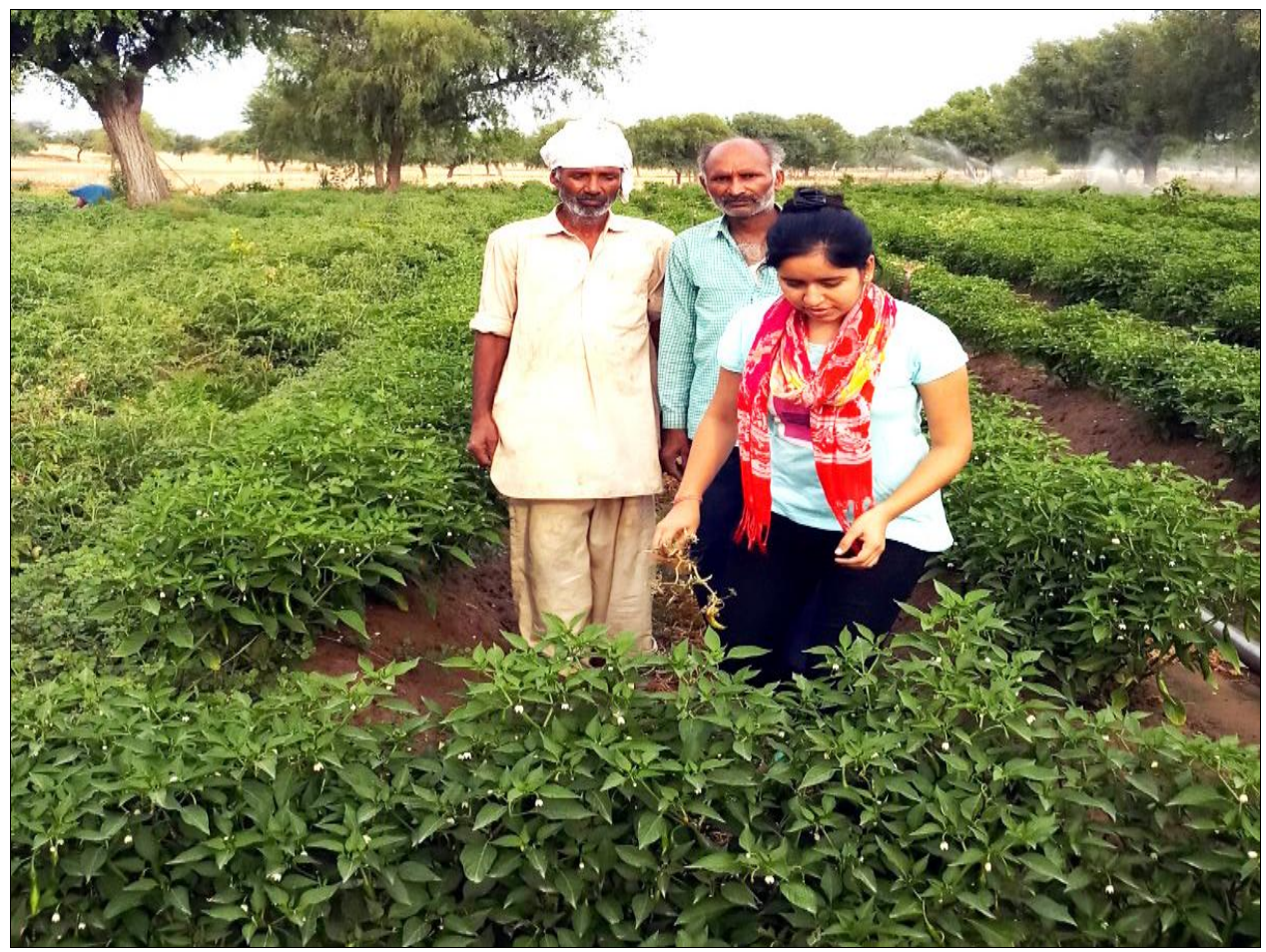


The maximum wilt intensity in Fatehabad district was observed in village Bhuna (7.9 per cent) and minimum wilt intensity was found in Diwana (1.0 per cent). Similarly, in Mahendragarh district the maximum wilt intensity was observed in Silarpur (7.3 per cent) and minimum wilt intensity was in Ateli (0.8 per cent). Hansi (5.2 per cent) of hisar district had maximum wilt intensity whereas Kharar-Alipur (0.5 per cent) had minimum wilt intensity.

VAM not only increase the uptake of phosphorous, but also helps in uptake of zinc, copper, sulphur, potassium and calcium (Cooper and Tinker 1978). Additionally, it protect plants against environmental stress such as soil salinity (Giri et al., 2003), drought (Al-Karaki et al., 2004) and pathogens such as Fusarium wilt (Habte et al., 1999). The population of mycorrhizal fungi was significantly correlated with the total $\mathrm{P}$ content in soil. Available $\mathrm{P}$ is negatively correlated with the occurance of mycorrhizal fungi in soil (Dudeja et al., 1997). The study indicates that, the mycorrhizal colonization was ranged from 1 to 17.3 per cent and sporocarp number in soil was ranged from 9 to 130 . The wilt intensity in chilli was ranged from 0.5 to 7.9. The mycorrhizal per cent colonization and number of sporocarp in soil was maximum in Mahendragarh (13.4 per cent mycorrhizal colonization and 83 sporocarps/ 100g soil) followed by Fatehabad district ( 7.5 per cent mycorrhizal colonization and 63.3 sporocarps/ 100g soil) and minimum in Hisar district (4.7 per cent mycorrhizal colonization and 39.4 sporocarps/ 100g soil) during the cropping season 2017-18. Similarly, Vani et al., (2014) conducted an extensive field survey in five major vegetable growing areas of district Anantnagand Kulgam of Kashmir valley (temperate region of India) and found that wilt disease (Fusarium wilt) occured in nursery at the time of transplantation but the maximum disease incidence was found during flowering/fruiting stage. Fusarium oxysporum not only cause wilting but also caused reduced growth of plant (Vidyasekharan and Thiagarajan, 1981). A survey of chilli fields were conducted by Umesha et al., (2005) and found the presence of bacterial wilt disease in important chilli growing regions of Karnataka. Disease incidence (26-32\%) was reported in state of Karnataka (India). The disease incidence varied from 6 - 24 per cent in Kadapa district (Andhra Pradesh) reported by Bai, et al., (2018). While Priya and Mesta (2018) conducted a survey in Belagavi, Gadag, Haveri districts and fund that the maximum wilt severity was 95 per cent during 2014-15.

\section{References}

Anonymous (2017). https://www.indiastat.com/agriculturedata/2/agricultural-productions.

Anonymous (2019). https://www.indiastat.com/agriculturedata/2/agricultural-productions.

Bai, S. A. T., Ruth. C., Gopal, K. and Arunodhayam, K. (2018). Survey and Identification of Fusarium wilt disease in chilli (Capsicum annuum L.). International Journal of Current Microbiology and Applied Sciences, 7(6):1073-1078.

Cooper, K. M. and Tinker, P. B. (1978). Translocation and transfer of nutrients in vesicular arbuscular mycorrhizas. Uptake and translocation of phosphorus, zinc and sulphur. New Phytologist, 81:43-52.

Dudeja, S. S., Bhardwaj, S. and Khurana, A. L. (1997). Effect of soil factors on the occurrence of vesicular arbuscular (VA) mycorrhizal fungi in Haryana soils. Natural Resource Management for Sustainable Production, 254-259.

Frank, A. B. Berdent Bot Gessel. (1885). 3:128-145. 
Gerdemann, J. W. and Nicolso, T. H. (1963). Spores of mycorrhizal Eadogone. species extracted from soil by wet sieving and decanting. Transaction of British Mycology Society, 46: 235-244.

Giri, B., Kapoor, R. and Mukerji, K. G. (2003). Influence of arbuscular mycorrhizal fungi and salinity on growth, biomass and mineral nutrition of Acacia auriculiformis. Biology and Fertility of Soils, 38: 170-175.

Habte. M., Zhang, Y. C. and Schmitt, D. P. (1999). Effectiveness of Glomus species in protecting white clover against nematode damage. Canadian Journal of Botany, 77:135-139.

Phillips, J. M. and Hayman, D. S. (1970). Improved procedure for clearing roots and staining parasitic and vesiculararbuscular mycorrhizal fungi for rapid assessment of infection. Transations Britis Myvological Society, 55: 158-161.
Priya, I. N. and Mesta, R. K. (2018). Survey for wilt of chilli: a threat to chilli crop in northern Karnataka. International Journal of Microbiology Research, 10(10): 1390-1391.

Saha, S., Chant, D. and McGrath, J. (2007). A systematic review of mortality in schizophrenia: is the differential mortality gap worsening over time. Archive of General Psychiatry, 64: 1123-1131.

Umesha, S., Kavitha, R. and Shetty, H. S. (2005). Transmission of seed-borne infection of chilli by Burkholderia solanacearum and effect of biological seed treatment on disease incidence. Archives of Phytopathology and Plant Protection, 38(4), 281-293.

Vidyasekharan, P. and Thiagarajan, C. (1981). P. seed borne transmission of Fusarium oxysporum in chilli. Indian Phytopathology, 34: 209-211.

\section{How to cite this article:}

Sarita and Rakesh Kumar Chugh. 2020. The Mycorrhizal Population Dynamics and Wilt Intensity in Chilli Growing Areas of Haryana. Int.J.Curr.Microbiol.App.Sci. 9(05): 3026-3033. doi: https://doi.org/10.20546/ijcmas.2020.905.360 